\title{
Collateral Ventilation: Friend or Foe in Patients with Severe Emphysema
}

\author{
Dirk-Jan Slebos $^{\mathrm{a}}$ Pallav L. Shah ${ }^{\mathrm{b}, \mathrm{c}}$ \\ ${ }^{a}$ Department of Pulmonary Diseases, University of Groningen, University Medical Center Groningen, Groningen, \\ The Netherlands; ${ }^{b}$ The National Institute for Health Research Unit, Royal Brompton and Harefield NHS Foundation \\ Trust and Imperial College, and ${ }^{C}$ Chelsea and Westminster Hospital NHS Foundation Trust, London, UK
}

Over the past decade, significant improvements have been made in developing nonpharmacological interventions to enhance lung mechanics in patients with severe emphysema [1]. Collateral ventilation has been an influential factor for some of the therapies and is defined as ventilation of the alveoli via pathways that bypass the normal bronchial airways. The initial randomized controlled trials with endobronchial valves failed to demonstrate clinically meaningful results as a proportion of the treated patients had collateral ventilation and hence did not develop lobar atelectasis [2]. Once the role of collateral ventilation was appreciated and patients were more carefully selected on the basis of formal measurements, remarkable benefits have been observed with mean improvements in $\mathrm{FEV}_{1}$ between 20 and 25\% [3-5]. Such is the importance of collateral ventilation that surrogate markers for collateral ventilation such as fissure integrity are formally assessed on the computed tomography scans at the screening stage and in the majority of patients formal measurements of collateral ventilation are performed by the Chartis procedure as recommended by the latest Best Practice Guidelines [6].

A significant proportion of patients with emphysema have collateral ventilation and hence alternative bronchoscopic techniques have been developed that work in-

\begin{tabular}{ll}
\hline KARGER & $\begin{array}{l}\text { ( ) } 2017 \text { The Author(s) } \\
\text { Published by S. Karger AG, Basel }\end{array}$ \\
$\begin{array}{l}\text { E-Mail karger@karger.com } \\
\text { www.karger.com/res }\end{array}$ & $\begin{array}{l}\text { Karger } \\
\text { This article is licensed under the Creative Commons Attribution- } \\
\text { NonCommercial-NoDerivatives 4.0 International License (CC BY- } \\
\text { NC-ND) (http://www.karger.com/Services/OpenAccessLicense). } \\
\text { Usage and distribution for commercial purposes as well as any dis- } \\
\text { tribution of modified material requires written permission. }\end{array}$
\end{tabular}

dependently of this physiological phenomenon. For this patient group, both endobronchial coils $[7,8]$ as well as sclerosing therapies [9-11] have shown potential as treatment options. Collateral ventilation thus seems the most important denominator in both chronic obstructive pulmonary disease and in bronchoscopic lung volume reduction. Where there is a dominant chronic obstructive pulmonary disease component, there is mucosal inflammation, bronchospasm, irregular airways, and mucus plugging. In this situation, the resistance of the airways is usually high leading to progressive air trapping, hypoxemia and hypercapnia. With progressive emphysema, there is destruction of the alveolar parenchyma increasing both intra- and interlobar collateral ventilation. Very early studies in excised emphysematous lungs confirmed that the resistance to collateral flow is much lower than the resistance in the airways [12]. This allows the exchange of gas even in obstructed segments and may account for the relative preservation of hypoxemia in emphysema patients.

In the past, several attempts have been made to take advantage of the abundant presence of collateral ventilation in severe emphysema by creating fenestrations - a so-called "airway bypass" - between the areas of trapped air and places where this air can easily be released. Early

Dr. Dirk-Jan Slebos, MD, PhD

Department of Pulmonary Diseases/Interventional Bronchoscopy AA11 University Medical Center Groningen, PO Box 30001

NL-9700 RB Groningen (The Netherlands)

E-Mail d.j.slebos@umcg.nl 
work in this field both showed potential using a transthoracic airway bypass approach $[13,14]$, as well as creating a bronchoscopic transbronchial airway bypass [15].

To prove the safety and efficacy of creating extra-anatomic airway bypasses between the most diseased areas of the lung and the large airways which were supported by paclitaxel drug-eluting stents to ensure patency, a randomized, full sham-controlled, multicenter trial (the EASE trial) was performed in patients with severe homogeneous emphysema [16]. The EASE trial showed that the airway bypass improved patient outcomes directly after the procedure; however, the durability of the effects was limited, and outcomes for both the sham-controlled and treatment groups were similar long after the procedure. Although the concept of creating an airway bypass was proven in this trial, the loss of airway bypass patency due to several factors caused the loss of the observed initial benefit [16].

In this issue of Respiration, Snell et al. [17] report on a unique treatment in a unique patient population whom they were able to follow for years after treatment with a transthoracic airway bypass. Creating a transthoracic airway bypass comes with a number of potential issues, such as thoracic surgery to create the bypass, with initially significant subcutaneous emphysema, frequent change of the bypass tubing, frequent interventions to clear out the bypass channel and of course also local esthetical issues. However, this paper again shows the great potential of creating functional collateral channels allowing emphysematous lungs to more easily empty and by those means improve their dyspnea symptoms. Based on this longterm follow-up, earlier reports, and our own observations $[16,18]$, we can only encourage further innovation and development of - preferably endoscopic - techniques that will allow this therapeutic approach to become more widely applicable for our highly symptomatic severe emphysema patients. Especially homogeneous emphysema patients with a high level of tissue destruction and who do have interlobar collateral ventilation seem to be the target patients for this therapy.

\section{References}

1 Shah PL, Herth FJ, van Geffen WH, Deslee G, Slebos DJ: Lung volume reduction for emphysema. Lancet Respir Med 2016, Epub ahead of print.

-2 Sciurba FC, Ernst A, Herth FJ, Strange C, Criner GJ, Marquette $\mathrm{CH}$, et al: A randomized study of endobronchial valves for advanced emphysema. N Engl J Med 2010;363:12331244.

3 Klooster K, ten Hacken NH, Hartman JE Kerstjens HA, van Rikxoort EM, Slebos DJ: Endobronchial valves for emphysema without interlobar collateral ventilation. N Engl J Med 2015;373:2325-2335.

4 Davey C, Zoumot Z, Jordan S, McNulty WH, Carr DH, Hind MD, et al: Bronchoscopic lung volume reduction with endobronchial valves for patients with heterogeneous emphysema and intact interlobar fissures (the BeLieVeRHIFi study): a randomised controlled trial. Lancet 2015;386:1066-1073.

5 Koster TD, Slebos DJ: The fissure: interlobar collateral ventilation and implications for endoscopic therapy in emphysema. Int J Chron Obstruct Pulmon Dis 2016;11:765-773.

6 Slebos DJ, Shah PL, Herth FJ, Valipour A: Endobronchial valves for endoscopic lung volume reduction: best practice recommendations from expert panel on endoscopic lung volume reduction. Respiration 2016, Epub ahead of print.
7 Sciurba FC, Criner GJ, Strange C, Shah PL, Michaud G, Connolly TA, et al: Effect of endobronchial coils versus usual care on exercise tolerance in patients with severe emphysema: the RENEW randomized clinical trial. JAMA 2016;315:2178-2189.

>8 Slebos DJ, Hartman JE, Klooster K, Blaas S, Deslee G, Gesierich W, et al: Bronchoscopic coil treatment for patients with severe emphysema: a meta-analysis. Respiration 2015;90: 136-145.

-9 Come CE, Kramer MR, Dransfield MT, AbuHijleh M, Berkowitz D, Bezzi M, et al: A randomised trial of lung sealant versus medical therapy for advanced emphysema. Eur Respir J 2015;46:651-662.

-10 Shah PL, Gompelmann D, Valipour A, McNulty WH, Eberhardt R, Grah C, et al: Thermal vapour ablation to reduce segmental volume in patients with severe emphysema: STEP-UP 12 month results. Lancet Respir Med 2016;4:e44-e45.

-11 Gompelmann D, Eberhardt R, Schuhmann M, Valipour A, Shah PL, Herth FJ, Kontogianni K: Lung volume reduction with vapor ablation in the presence of incomplete fissures: 12-month results from the STEP-UP randomized controlled study. Respiration 2016;92:397-403.

12 Hogg JC, Macklem PT, Thurlbeck WM: The resistance of collateral channels in excised human lungs. J Clin Invest 1969;48:421-431.
13 Junior RS, Neto VD, Botter M, Stirbulov R, Rivaben JH, Gonçalves R: Therapeutic application of collateral ventilation with pulmonary drainage in the treatment of diffuse emphysema: report of the first three cases. J Bras Pneumol 2009;35:14-19.

14 Moore AJ, Cetti E, Haj-Yahia S, Carby M, Björling G, Karlsson S, Shah P, Goldstraw P, Moxham J, Jordan S, Polkey MI: Unilateral extrapulmonary airway bypass in advanced emphysema. Ann Thorac Surg 2010;89:899-906.

15 Choong CK, Macklem PT, Pierce JA, Das N, Lutey BA, Martinez CO, Cooper JD: Airway bypass improves the mechanical properties of explanted emphysematous lungs. Am J Respir Crit Care Med 2008;178:902-905.

16 Shah PL, Slebos DJ, Cardoso PF, Cetti E, Voelker K, Levine B, Russell ME, Goldin J, Brown M, Cooper JD, Sybrecht GW; EASE trial study group: Bronchoscopic lung-volume reduction with Exhale airway stents for emphysema (EASE trial): randomised, shamcontrolled, multicentre trial. Lancet 2011;378: 997-1005.

17 Snell GI, Holsworth L, Khorramnia S, Westall GP, Williams TJ, Marasco S, Gooi JH: Feasibility and safety of a transthoracic pneumostoma airway bypass in severe emphysema patients. Respiration 2017;93:236-246.

18 Slebos DJ, Klooster K, Erasmus M: Emphysema! Am J Respir Crit Care Med 2012;186: 197. 